\title{
Iron Deficiency Defined by Hepcidin in Critically III Patients
}

\author{
Michele F. Eisenga* (10
}

Lasocki et al. recently published in Critical Care in a controlled, randomized, single-blinded, multicenter trial that treatment of iron deficiency (ID), according to hepcidin levels, resulted in a significant reduction of the risk in mortality in critically ill patients 90 days after ICU discharge and an improved 1-year survival rate [1]. The authors defined ID by hepcidin, measured with mass spectrometry. An absolute ID was defined as a hepcidin level $<20 \mu \mathrm{g} / \mathrm{L}$ and a functional ID as a hepcidin level of $20 \mu \mathrm{g} / \mathrm{L}$ to lower than $41 \mu \mathrm{g} / \mathrm{L}$. It is an interesting approach to define ID based on hepcidin levels, however, it is questionable whether this concerns the most appropriate option to determine ID.

First, in other inflammatory settings such as heart failure, it has been shown that hepcidin was not an accurate diagnostic marker for ID based on the gold standard of bone marrow iron staining [2]. When assessing bone marrow aspirates on iron stores and percentage sideroblasts (absolute vs. functional ID), hepcidin had low diagnostic accuracy, whereas a standard cut-off of transferrin saturation $($ TSAT) $<19.8 \%$ had excellent diagnostic accuracy. Table S3 clearly shows that patients within the intervention ID group, on which the conclusions are based by Lasocki et al., have an upper interquartile range of TSAT of $27 \%$, questioning whether this group had ID at ICU discharge.

Second, hepcidin levels are being influenced by myriad causes [3]. The authors regard ID as the driving force

This comment refers to the article available online at https://doi.org/10.1186/ s13054-020-03430-3.

*Correspondence: m.f.eisenga@umcg.nl

Department of Internal Medicine, Division of Nephrology, University Medical Center Groningen, P.O. Box 30.001, 9700 RB Groningen, The Netherlands behind the low hepcidin levels, even in the presence of inflammation. The latter is well-established; however, it would be of added value to exclude other potential contributing factors, and confirm that the low hepcidin levels at ICU discharge are attributable to ID. Apart from cirrhosis, no information is given about liver disease. Liver disease (e.g., chronic hepatitis $\mathrm{C}$ infection or autoimmune liver disease) has been shown to lower hepcidin levels already before the cirrhosis stage [4]. Similarly, alcohol consumption has been shown to lower hepcidin levels [3]. Finally, specific medications such as steroids, commonly used in the ICU setting, are not reported. Previously, we showed that 24-h urinary prednisolone levels are an important negative determinant of serum hepcidin levels in kidney transplant recipients [5]. Providing extra data about these specific aspects would further strengthen the results by Lasocki et al. and show that the low hepcidin levels in the intervention arm are truly attributable to ID although the TSAT levels, in part, are completely within the normal range.

\footnotetext{
Authors' response

Sigismond Lasocki ${ }^{2 *}$ iD , Samir Jaber ${ }^{3}$, Thibaud Lefebvre and Sylvain Lehmann ${ }^{5}$ on behalf of the Hepcidane study group

${ }^{*}$ Correspondence: sigismond@lasocki.com

${ }^{2}$ Département Anesthésie Réanimation, Université d'Angers, CHU Angers,

4 rue Larrey, 49933 Angers Cedex 9, France

${ }^{3}$ Département Anesthésie Réanimation, Université de Montpellier, Montpellier, France

${ }^{4}$ Centre de Recherche Sur L'Inflammation, INSERM U1149, UFR de Médecine Bichat; Assistance Publique des Hôpitaux de Paris, APHP Nord Hôpital Universitaire Louis Mourier, - Colombes (France); Laboratoire D'Excellence GR-Ex Ou Laboratory of Excellence GR-Ex, Université de Paris, Paris, France

${ }^{5}$ Laboratoire de Biochimie Protéomique Clinique Et IRMB INSERM, CHU de Montpellier, Université de Montpellier, Montpellier, France
}

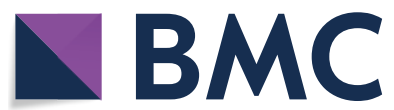

(c) The Author(s) 2021. Open Access This article is licensed under a Creative Commons Attribution 4.0 International License, which permits use, sharing, adaptation, distribution and reproduction in any medium or format, as long as you give appropriate credit to the original author(s) and the source, provide a link to the Creative Commons licence, and indicate if changes were made. The images or other third party material in this article are included in the article's Creative Commons licence, unless indicated otherwise in a credit line to the material. If material is not included in the article's Creative Commons licence and your intended use is not permitted by statutory regulation or exceeds the permitted use, you will need to obtain permission directly from the copyright holder. To view a copy of this licence, visit http://creativecommons.org/licenses/by/4.0/. The Creative Commons Public Domain Dedication waiver (http://creativeco mmons.org/publicdomain/zero/1.0/) applies to the data made available in this article, unless otherwise stated in a credit line to the data. 


\section{Yes, Hepcidin is a good indicator of iron treatment in the critically ill}

Michele Eisenga is right when he claims that iron deficiency (ID) diagnosis is challenging, notably in presence of inflammation. He advocates the use of a low $(<20 \%)$ transferrin saturation (TSAT) to define ID in these patients, based on a cohort of 42 patients scheduled for cardiac surgery in whom a TSAT $<20 \%$ was more predictive of ID, diagnosed on bone marrow examination, than hepcidin (measured using an ELISA method) [2]. However, these patients did not have significant inflammation (their median CRP was only $2 \mathrm{mg} / \mathrm{L}$ ), contrary to ours (median CRP $68 \mathrm{mg} / \mathrm{L}$ ). One should also keep in mind that TSAT is a calculated parameter, based on transferrin and serum iron measurement, and serum iron has nychthemeral variations. The timing of blood sampling is thus important. At last, in our study population, more than three-quarters of the patients had a TSAT $<20 \%$, mainly because of inflammation [1]. Indeed, TSAT could be decreased either because of low iron stores or because of high inflammation, which prevents iron release from stores; when hepcidin is decreased in case of low iron stores and increased in presence of inflammation, so it is probably a better indicator of the balance between low stores and the impossibility to release iron (Fig. 1) [6]. Hepcidin plays a key role in iron metabolism, it prevents the release of iron by blocking the ferroportin directly. Hepcidin is thus not only "a biomarker" of ID but has a biological role. That is why we proposed hepcidin to diagnose ID in critically ill patients [7].

Most importantly, we believe that it is more important to find a marker that predicts the response to iron therapy, rather than a marker that predicts low iron stores only. A low TSAT could be useful in heart failure patients as proposed by Grote Beverborg et al. [2], but in critically ill patients we believe that hepcidin may help improve mortality. We have previously show in a cohort of 1161 critically ill patients that a low hepcidin was associated with increased one-year mortality [8], and we now have shown in this randomized controlled trial that a treatment strategy of iron \pm erythropoietin based on hepcidin quantification reduced long term mortality [1]. We will probably never have a unique definition for ID, but rather context specific markers that will help clinicians at the bedside to decide on iron treatment according to the expected outcomes. In critically ill it is probably hepcidin.

\section{Acknowledgements}

None.

\section{Authors' contributions}

MFE wrote the manuscript and approved final version.

Funding

None.

Availability of data and materials

Not applicable.

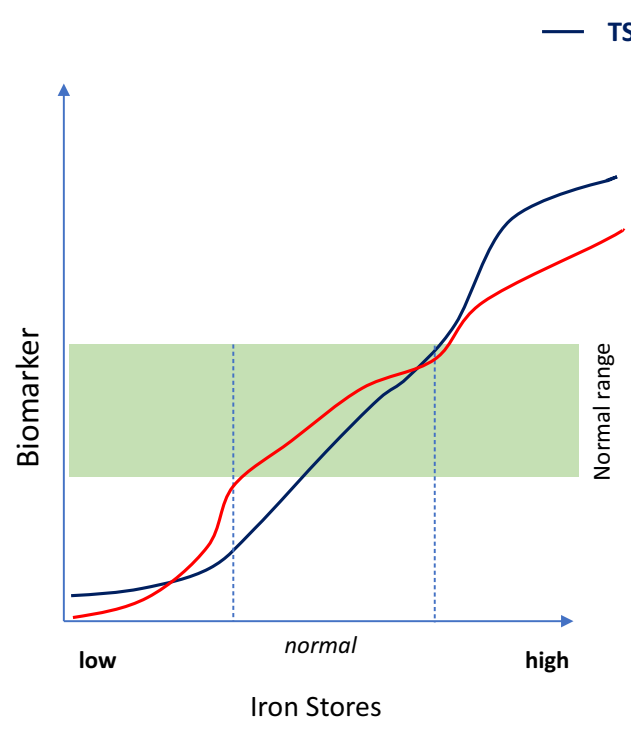

Absence of inflammation

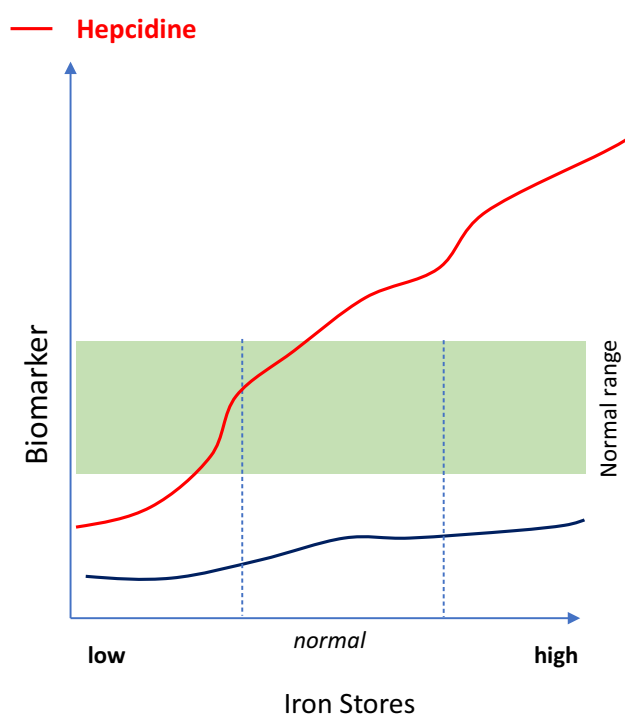

Inflammatory states

Fig. 1 Schematic representation of iron deficiency biomarker variation according to iron stores and inflammation. TSAT, Transferrin saturation. This graph represents the expected variations of TSAT (blue lines) and hepcidin (red lines), according to the level of iron stores and in absence of inflammation (left panel) or in case of inflammatory states (right panel) 


\section{Declarations}

Ethics approval and consent to participate

Not applicable.

\section{Consent for publication}

Not applicable.

\section{Competing interests}

MFE received consulting and speaking fees from Vifor Pharma and served the Advisory Board of Cablon Medical.

Received: 19 February 2021 Accepted: 11 March 2021

Published online: 12 April 2021

\section{References}

1. Lasocki S, Asfar P, Jaber S, Ferrandiere M, Kerforne T, Asehnoune K, et al. Impact of treating iron deficiency, diagnosed according to hepcidin quantification, on outcomes after a prolonged ICU stay compared to standard care: A multicenter, randomized, single-blinded trial. Crit.Care. 2021;25:62. https://doi.org/10.1186/s13054-020-03430-3

2. Grote Beverborg N, Klip IT, Meijers WC, Voors AA, Vegter EL, van der Wal $\mathrm{HH}$, et al. Definition of iron deficiency based on the gold standard of bone marrow iron staining in heart failure patients. Circ Heart Fail. 2018;11:e004519.

3. Girelli D, Nemeth E, Swinkels DW. Hepcidin in the diagnosis of iron disorders. Blood. 2016;127:2809-13.
4. Vela D. Low hepcidin in liver fibrosis and cirrhosis; a tale of progressive disorder and a case for a new biochemical marker. Mol Med. 2018;24:5

5. Eisenga MF, Dullaart RPF, Berger SP, Touw DJ, Bakker SJL, Gaillard CAJM. Urinary prednisolone excretion is a determinant of serum hepcidin levels in renal transplant recipients. Am J Hematol. 2017:92:E173-5.

6. Lasocki S, Longrois D, Montravers P, Beaumont C. Hepcidin and anemia of the critically ill patient. Anesthesiology. 2011;114(3):688-94.

7. Lasocki S, Baron G, Driss F, Westerman M, Puy H, Boutron I, Beaumont C, Montravers P. Diagnostic accuracy of serum hepcidin for iron deficiency in critically ill patients with anemia. Intensive Care Med. 2010;36(6):1044-8

8. Lasocki S, Lefebvre T, Mayeur C, Puy H, Mebazaa A, Gayat E. group F-Is: Iron deficiency diagnosed using hepcidin on critical care discharge is an independent risk factor for death and poor quality of life at one year: an observational prospective study on 1161 patients. Crit Care. 2018;22(1):314

\section{Publisher's Note}

Springer Nature remains neutral with regard to jurisdictional claims in published maps and institutional affiliations.
Ready to submit your research? Choose BMC and benefit from:

- fast, convenient online submission

- thorough peer review by experienced researchers in your field

- rapid publication on acceptance

- support for research data, including large and complex data types

- gold Open Access which fosters wider collaboration and increased citations

- maximum visibility for your research: over $100 \mathrm{M}$ website views per year

At BMC, research is always in progress.

Learn more biomedcentral.com/submissions 